\title{
Studying Relationship between Organizational Climate and Developing Entrepreneurial Spirit among Postgraduate Students (The Case of University of Isfahan)
}

\author{
Salman Darabi \\ MA Student, Faculty of Educational Sciences and Psychology, University of \\ Isfahan, Isfahan, Iran \\ Mohamadreza Neyestani \\ Assistant Professor, Faculty of Educational Sciences and Psychology, University of \\ Isfahan, Isfahan, Iran
}

Mohamad Ghafari

$\mathrm{PhD}$ Student, Department of Management, Faculty of Administrative Science and Economics, University of Isfahan, Isfahan, Iran

Katayoon Maidanipour

Master of Educational Planning, Faculty of Educational Sciences and Psychology, Tehran University, Iran

Seyedmohammad Mard

$\mathrm{PhD}$ Student of Educational Management, Faculty of Educational Sciences and Psychology, Kharazmi University, Iran

Accepted: Jan 17, 2013 Published: Feb 27, 2013

Doi:10.5296/jsr.v4i1.2916 URL: http://dx.doi.org/10.5296/jsr.v4i1.2916

\begin{abstract}
Developing entrepreneurship spirit between students is one of the most important planning goals in every university. In order to developing entrepreneurial spirit and skills between students, every university has to possess appropriate organizational climate. Organizational climate reflects the employees' perceptions and perspectives of university as organization and shows the values, the beliefs and the attitudes that help the university work to positive changes. Based on the importance of relationship between organizational climate and developing entrepreneurial spirit especially between students, the aim of this study is to investigate the relationship between organizational climate of the university and students'
\end{abstract}


entrepreneurial spirit. The correlation research was designed to determine the degree of relationship between variables. The statistical population of this study was all postgraduate students of Isfahan of University. Total of students participated in survey included 120 female and 100 male students in 2011. Two instruments- organizational climate questionnaire which was adopted from Halpin and Craft's and the researcher-developed questionnaire regarding entrepreneurial spirit were distributed between participants. Reliability coefficient for questionnaire of the organizational climate was $83 \%$ and for questionnaire of entrepreneurial spirit was $89 \%$. Inferential statistics were used to answer the research questions. The findings indicated that there is a significant relationship between organizational climate and students' entrepreneurship spirit. According to the results of multiple regression analysis held between sub-dimensions of organizational climate and students' entrepreneurship spirit, the findings proved the fact that organizational climate have a significant relationship with creativity, internal control and the achievement; however, it did not relate significantly with risk-taking and autonomy.

Keywords: organizational climate, entrepreneurial spirit, higher education, psychological factors

\section{Introduction}

The historical trends of countries economic and industrial developments indicated that entrepreneurship and the significant relationship between science and technology in the manpower market is one of the important factors to development, growth, and also economic and cultural progresses. Indeed, development of each country is depended on appropriate utilization of all facilities especially human resources, that this considered as one of the most important and key capitals of each country. The entrepreneurship is needed to providing work, creating revolution through innovations and developments in procedures as a critical factor in economic development and growth.

In the nowadays world some factors such as entrepreneurial activities, having entrepreneurial sprits and being the entrepreneur lead to economic revolution, social, and industrial conditions (Antoncic, 2003). The knowledge that formed in professional human resources and technology is important for economic development (Oueik, 1996). All of which studies that conducted in terms of entrepreneurship area are based on three approaches that include psychological, social, and economic approaches. The psychological approach examines individual traits of entrepreneurs. The social approach refers to studying the role of entrepreneur's interactions in society. Finally the economic approach refers to studying economic impacts of entrepreneurs society. (Zabihi, 2006) In the new paradigm, that defined as knowledge-based economic and post-industrial area, publication and utilization of knowledge has many importance and because of this, academic systems of countries has many increasingly importance.

The rapid population growth and incrementally increasing in unemployment rate especially 
between graduates is one of the important challenges that many societies handle it. The academic system of each country as one side of education has responsibility to educating professional and efficient human resources that are needed to society in all levels and academic fields. Attracting the universities' graduates and high educational institutes is depended on having which abilities and traits and some of them should provide in universities. There are some factors that create problems in work issues, including mismatch between capacity of universities and the future needs of labor market, mismatch between educational courses and job skills, universities' inability to providing and reinforcing scientific esprit between students, the minimum levels of academic and practical competencies for graduates, lack of appropriate grounds for scientific and practical educations, inefficiency of faculty members in order to educating professionals that the society needs them, decreasing motivation and self-esteem between students, and finally risk-avoiding sprits between them (Ghasemi, 2010).

The academic system has many important and especial functions in every society that escaping peoples from inability, educating and directing them toward labor market are important instances of these (Emaminejhad, 2004). Therefore which society has graduates that are able to providing creative and efficient production resources and performing job with their creative efforts and being entrepreneurship will achieve its goals (Jaribi, 2004).

Therefore the economic and technological revolutions in later decades refer to important role of production, distribution, and knowledge utilization in economic powers especially in developing countries. This also leads to some challenges in scientific and academic systems and also revolutionizing them. In other words, it is expected that academic system undertake some other important roles with comprehensive interaction with economic and industrial sections through publication of knowledge in order to economic development in addition to its traditional role in education and research.

\section{Organizational climate}

Organizational climate is the achievement of efforts, relationships, and interactions between internal groups of academic systems including managers, professors, staffs, and students. This is the reflection of procedures, shared believes, and value systems of an organization. The climate refers to member's perception from environment and this influence by formal and informal organization, individual's personality, and organizational leadership. In other words, this is the set of internal characteristics of organizations that influence their member's behavior, encourage them to active and effective work, or maybe encourage inability and apathy toward work and organization between them.

Therefore the appropriate climate is necessary to educating creative and entrepreneurial sprits. The academic system need to which climate that students educated as creative and innovative professionals for future (Zahedi, 2003). Our universities' climate should educate students that strive to achievement. These characteristics need to freedom, favorable, and participative 
climate (Samadi, 2007). The academic system in this study includes the following sub-factors of organizational climate:

1. Devotion: refers to amount of correlation and social interactions between members.

2. Interest: refers to individual's intention to participating in academic affairs.

3. Community spirit: refers to which condition that members enjoy from participating with each other.

4. Influence and dynamics: the dynamic behavior that the universities' managements introduce themselves as hardworking.

5. Disturbance: refers to amount that members consider rules, official procedures, and management as deterrent factors.

6. Regarding: this dimension refers to manager's friendship and humanity behavior. The manager who wants to behaves members in humanity manners.

7. Focus on production: refers to amount that the academic management forces staffs to hardworking.

8. Avoidance: refers to manager's formal and impersonal behavior that manager avoids from his/her job and like to rules and procedures dominance in university.

These dimensions are the measures of organizational climate that in this study their relationships with entrepreneurial spirit have been examined. Hipline and Crafts introduced six climates to describing organizational climate. But in this study our focus was on two climates including open and close. The first refers to high levels of devotion and community spirit, regarding and influence; lower levels of deterrent and disaffection between students, focus on production and avoidance behaviors. And the second includes: lower levels of devotion and community spirit, regarding and influence; high levels of deterrent and disaffection between students; focus on production and avoidance behaviors (Halpin and Croft, 1963).

Therefore the favorable and sound organizational climate creates which conditions that professional management and leadership can achieve in this through sound interpersonal relationships and also increase individual's motivation and interest toward individual, organizational, and social goals. This also leads to growth of individual and group abilities and making academic climates and plans more efficiency and effectiveness.

\section{Entrepreneurial spirit}

The entrepreneur is one who organizes, manages, and accepts risks of investments or plans (Mehrabi, 2004). Shoumpiters defined entrepreneurship as the main motivating force in economic development and also considered this as creativity-destructive process. In other word, the main characteristic of entrepreneurship is doing new works or introducing modern methods in doing current works (Zadegan, 2004). Also entrepreneurship is the creation of valuable insight from nothing, the process of accessing opportunities and persuading them regardless of existing resources(Timmons). 
Providing and reinforcing entrepreneurial spirit is one of the important issues in entrepreneurship discussions. In other words, organizations caneducate their staffs and move them toward entrepreneurship organization through educational plans, motivation to progress, risk-taking, autonomy, creativity, innovation, and other dimensions of entrepreneurship. There are three approaches in terms of educating entrepreneurship spirit including personality, demographic, and finally attitude approaches. In this study, we utilize the attitude approach that its dimensions include:

- Motivation to progress: includes individual's tendency to doing work by high level standards in order to achievement in competitive conditions.

- Risk-taking: includes accepting moderate risks that could restrain through individual efforts.

- Autonomy (independency)

- Internal control:means that individuals consider themselves as sources of failures and achievement, not external factors such as environment or other peoples.

Some of factors influence increasing entrepreneurship spirits include psychological, academic, educational, individual, and finally professional factors that each of these influences entrepreneurship spirit in academic environments. The psychological factors focused in current study. These factors indicated in fig 1.

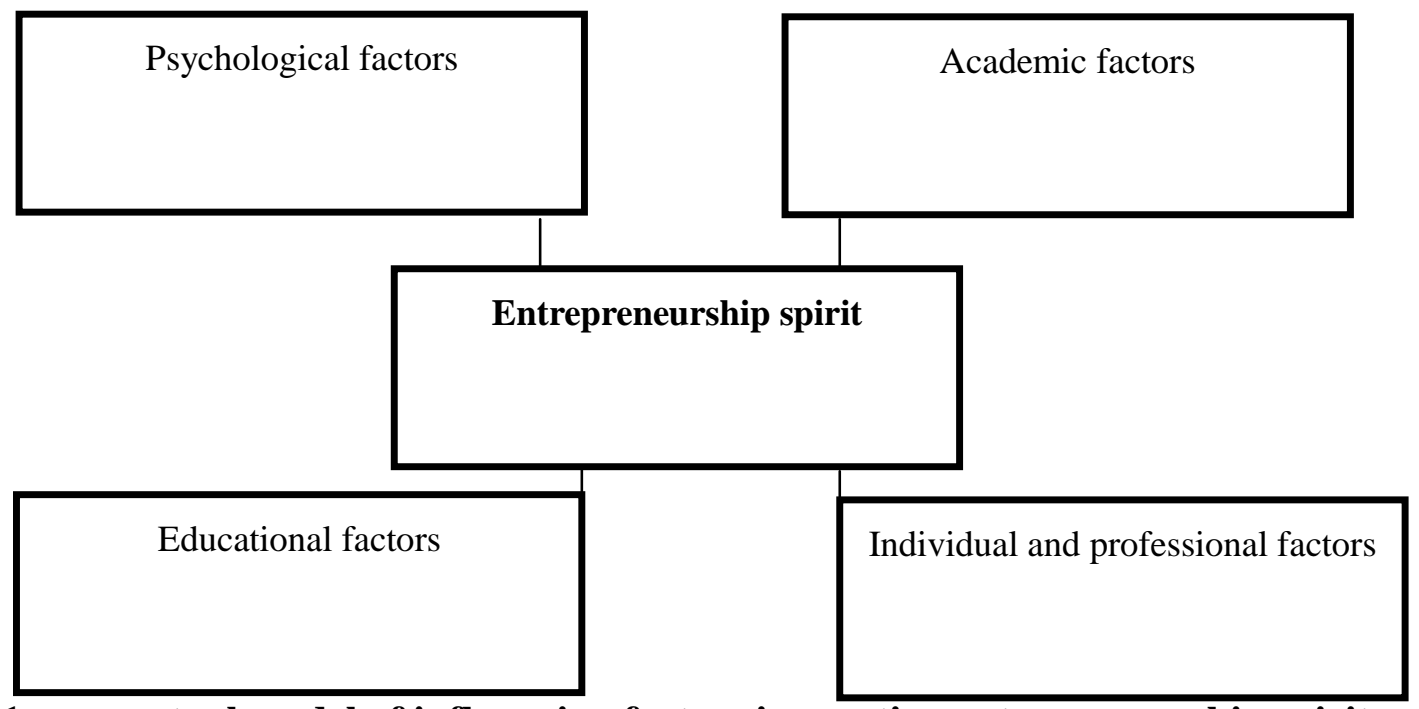

Fig 1: conceptual model of influencing factors in creating entrepreneurship spirit

With respect to that current area is changing and revolution area; there are some factors that influence peoples willingly or unwillingly. These factors include rapid environmental changes, complexity and competitiveness conditions in global trends, rapid population growth, and increasing unemployment rate, unfair distribution of wealth and income, and unfavorable quality of life. Therefore the society that has graduates who can provide production resources through creativity and dynamics and conduct businesses through creative efforts and being entrepreneur will be successful. In order to this, providing appropriate climate in educational 
and academic centers is very important. With respect to this description, the academic system should be able to actualizing characteristics such as creativity, self-esteem, prediction, risk-taking, intention to achievement (entrepreneurship spirit) between students. Therefore providing jequirities of actualizing such characteristics between individuals to achieving idealistic society is one of the main functions of academic institutes.

There are many studies that conducted in area of such issues, for example Zampetakis and others (2009) in their study entitled "entrepreneurship trends in organizations" resulted that the staffs who receive higher levels of organizational supportiveness, then they have more commitment to their organization and also have higher performance. Also Rashid (2000) in his study in terms of the role of education on increasing attitudes and entrepreneurship characteristics resulted that individuals who influence by some of especial entrepreneurship educations, could achieve high grates in terms of motivation to progress, internal source of control, self-esteem, and creativity. Mousavi (2004) examined the relationship between organizational climates with employee's job burnout at Mazandaran University of medical sciences and finally resulted that there is significant relationship between organizational climates and job burnout. He suggested that if the organizational climate is favorable leads to decreasing job burnout. Zampetakis (2009) in his study resulted that the employees who receive higher levels of organizational supportiveness, then have more commitment to their organization and also have higher levels of performance.

Therefore we want to answer these questions in current study:

1: what is amount of measures of entrepreneurship spirit between graduate students in university of Isfahan?

2: is there relationship between organizational climate and components of entrepreneurship spirit of postgraduate students in university of Isfahan?

3: is there relationship between organizational climate and educating entrepreneurial spirit between postgraduate students in university of Isfahan?

4: is there relationship between components of organizational climate and educating entrepreneurship spirit between postgraduate students of university of Isfahan?

\section{Research methodology}

This study was descriptive-correlation based on its issue's nature and its purposes. The statistical population of this study was all of male and female postgraduate students in university of Isfahan in 2011. Based on the statistical size of our statistical population were 4000 students. In order to collecting data and conducting results, 220 students were selected through random classification sampling method and then 120 questionnaires were distributed between female students and remaining 100 questionnaires were distributed between male students. In order to collecting data, the self-developed questionnaire was utilized. This questionnaire consists of two sections including organizational climate and entrepreneurship spirit section. In order to examining stability of this questionnaire, Cronbach's Alpha has 
been measured for each of two sections respectively $83 \%$ for organizational climate and $89 \%$ for entrepreneurship spirit. This questionnaire includes 32 items to measuring organizational climate (based on Haplin and Craft) and also 30 items to measuring entrepreneurship spirit. In order to analyzing data and concluding results, descriptive and inferential statistics and some methods such as correlation coefficient, multiple regression analysis, and t-test has been utilized.

\section{Findings}

In this sections the studies questions were analyzed based on the collected data. In order to this, correlation coefficient, multi-step analysis of regression and t-test has been used. In order to answering the first question of study, one sample t-test has been used. This question asks what is amount of measures of entrepreneurship spirit between graduate students in university of Isfahan? The results of this test have been indicated at the table 1.

Table 1: the results of t-test to measuring amount of measures of entrepreneurship spirit between postgraduate students

\begin{tabular}{|c|c|c|c|c|}
\hline $\begin{array}{r}\text { Dimensions of entrepreneurship } \\
\text { spirit }\end{array}$ & $\begin{array}{r}\text { Sample } \\
\text { size }\end{array}$ & $\mathbf{t}$ & mean & sig \\
\hline Risk-taking & 220 & $5 / 054$ & $3 / 145$ & $0 / 000$ \\
\hline Creativity & 220 & $0 / 688$ & $3 / 023$ & $0 / 492$ \\
\hline Internal control & 220 & $14 / 43$ & $3 / 596$ & $0 / 000$ \\
\hline Motivation of Progress & 220 & $10 / 58$ & $3 / 462$ & $0 / 000$ \\
\hline Autonomy & 220 & $15 / 82$ & $3 / 722$ & $0 / 000$ \\
\hline
\end{tabular}

As indicated at the table 1, amount of risk, creativity, control, achievement, and autonomy was more than moderate value (3) (with $\mathrm{p}<0 / 05$ ), also the most value was for autonomy dimension with mean $3 / 72$ and the lowest value was for creativity with mean $0 / 02$.

Then in order to answering the second question of study, correlation coefficient been used. This question indicated that is there relationship between organizational climates with components of entrepreneurship spirit of postgraduate students in university of Isfahan? The results of this test have been indicated at the table 1 .

Table 2: the results of correlation coefficient of entrepreneurship spirit between postgraduate students

\begin{tabular}{|c|c|c|c|c|}
\hline $\begin{array}{c}\text { Climate of academic system and } \\
\text { educating entrepreneurship spirit }\end{array}$ & $\begin{array}{r}\text { Sample } \\
\text { size }\end{array}$ & mean & $\begin{array}{r}\text { Correlat } \\
\text { ion } \\
\text { coefficient }\end{array}$ & sig \\
\hline Organizational climate & 220 & $3 / 010$ & $0 / 291^{* *}$ & $0 / 000$ \\
\hline
\end{tabular}




\begin{tabular}{|r|r|r|r|}
\hline Educating entrepreneurship spirit & 220 & $16 / 95$ & \multirow{2}{*}{} \\
\cline { 1 - 3 } & $\mathrm{p}>\mathrm{p} 0 / 01^{* *} \quad \mathrm{p}<0 / 05^{*}$ & & \\
\hline
\end{tabular}

The results of statistical analysis indicated that significant correlation $(0 / 291)$ between organizational climate and educating entrepreneurship spirit was found with $p<0 / 01$.

Then in order to answering the third question, correlation coefficient has been used. This question indicated that is there relationship between organizational climate and educating entrepreneurship spirit between postgraduate students in university of Isfahan? The results of this test have been indicated at the table 3 .

Table 3: the results of correlation coefficient between organizational climate and components of educating entrepreneurship spirit

\begin{tabular}{|c|c|c|r|r|c|}
\hline Variable & $\begin{array}{r}\text { Risk-taki } \\
\mathbf{n g}\end{array}$ & $\begin{array}{r}\text { Educatin } \\
\text { g creativity }\end{array}$ & $\begin{array}{r}\text { Educating } \\
\text { internal } \\
\text { control }\end{array}$ & $\begin{array}{r}\text { Educating } \\
\text { achievement }\end{array}$ & $\begin{array}{r}\text { Educating } \\
\text { autonomy }\end{array}$ \\
\hline $\begin{array}{r}\text { Organizational } \\
\text { climate }\end{array}$ & $-050 / 67 \%$ & $0 / 175^{* *}$ & & $0 / 367^{* *}$ & $0 / 101^{* *}$ \\
\hline & $\mathrm{p}>\mathrm{p} 0 / 01^{* *}$ & $\mathrm{p}<0 / 05^{*}$ & $0 / 199^{* *}$ & & \\
\hline
\end{tabular}

Based on the correlation coefficient (table 3),it is resulted that only creativity, internal control, and achievement have relationship with organizational climate. Indeed, there is significant relationship between components of educating entrepreneurship spirit (creativity, internal control, and achievement) with organizational climate. These correlations were respectively $0.367,0.199$, and 0.175 with 0.01 significant. In other words, it is should remember that increasing level of organizational climate leads to increasing students' creativity, internal control, and achievement.

In order to answering the fourth question that indicated is there relationship between components of organizational climate and educating entrepreneurship spirit between postgraduate students in university of Isfahan, Pearson correlation has been used. The results of this analysis indicated at the table 4 .

Table 4: correlation coefficient between components of organizational climate and components of educating entrepreneurship spirit

\begin{tabular}{|r|r|r|r|r|r|}
\hline $\begin{array}{r}\text { of } \\
\text { components } \\
\text { organizational climate }\end{array}$ & Autonomy & $\begin{array}{r}\text { Progress } \\
\text { motivation }\end{array}$ & $\begin{array}{r}\text { Inner } \\
\text { control }\end{array}$ & Creativity & Risk-taking \\
\hline
\end{tabular}




\begin{tabular}{|c|c|c|c|c|c|c|}
\hline \multicolumn{7}{|c|}{$\begin{array}{r}\text { educating entrepreneurship } \\
\text { spirit }\end{array}$} \\
\hline \multirow[t]{2}{*}{ Disturbance } & $\begin{array}{r}\text { Correlation } \\
\text { coefficient }\end{array}$ & -.089 & -.067 & -.177 & -.112 & .042 \\
\hline & sig & .187 & .321 & .009 & .099 & .523 \\
\hline \multirow[t]{2}{*}{ Devotion } & $\begin{array}{l}\text { Correlation } \\
\text { coefficient }\end{array}$ & .118 & .164 & .122 & .070 & .039 \\
\hline & sig & .082 & .015 & .072 & .299 & .567 \\
\hline \multirow[t]{2}{*}{ Regarding } & $\begin{array}{r}\text { Correlation } \\
\text { coefficient } \\
\end{array}$ & .026 & .156 & .071 & .040 & -.031 \\
\hline & sig & .706 & .021 & .296 & .556 & .649 \\
\hline \multirow[t]{2}{*}{ Interest } & $\begin{array}{r}\text { Correlation } \\
\text { coefficient }\end{array}$ & .055 & .200 & .254 & .018 & -.018 \\
\hline & sig & .419 & .003 & .000 & .793 & .795 \\
\hline \multirow[t]{2}{*}{ Avoidance } & $\begin{array}{r}\text { Correlation } \\
\text { coefficient } \\
\end{array}$ & .026 & .197 & .071 & .165 & -.031 \\
\hline & sig & .704 & .003 & .294 & .014 & .644 \\
\hline \multirow[t]{2}{*}{$\begin{array}{r}\text { Influence and } \\
\text { dynamics }\end{array}$} & $\begin{array}{r}\text { Correlation } \\
\text { coefficient }\end{array}$ & .098 & .374 & .215 & .200 & -.032 \\
\hline & sig & .149 & .000 & .001 & .003 & .638 \\
\hline \multirow[t]{2}{*}{$\begin{array}{l}\text { Focus on } \\
\text { production }\end{array}$} & $\begin{array}{r}\text { Correlation } \\
\text { coefficient }\end{array}$ & .055 & .233 & .131 & .210 & -.854 \\
\hline & sig & .414 & .000 & .051 & .002 & .023 \\
\hline \multirow[t]{2}{*}{$\begin{array}{r}\text { Community } \\
\text { spirit }\end{array}$} & $\begin{array}{r}\text { Correlation } \\
\text { coefficient }\end{array}$ & .120 & .172 & .072 & .098 & -.007 \\
\hline & sig & .075 & .010 & .288 & .147 & .913 \\
\hline
\end{tabular}

The results of table 4 indicated that there is significant negative relationship between disturbance of organizational climate with internal control $(\mathrm{R}=-0.177)$ in order to educating entrepreneurship spirit. This mean of this is that if disturbance increased in organizational climate, then internal control decreased. Also there is significant relationship between disturbance with internal control with $9=0.005$. Also there is significant positive correlation between interest of organizational climate with internal control and motivation to progress in educating entrepreneurship spirit respectively -0.254 and -0.200 . Also there is significant positive relationship between influence and dynamics dimensions of organizational climate with creativity, internal control, and motivation to progress in educating entrepreneurship spirit respectively $0 / 200,0.215$, and 0.374 , but there isn't any relationship between this and autonomy and risk-taking. Then there is significant negative relationship between dimension of focus on production with risk-taking $(\mathrm{R}=0.854$. Also there is significant relationship between organizational climate, motivation to progress in educating entrepreneurship spirit respectively 0.210 and 0.323 , but there isn't relationship between this with risk-taking and autonomy. 
The results of analysis of regression help us to predicting relationships dimensions of organizational climate with educating entrepreneurship spirit and also help us to determine which of organizational structure dimensions predict educating entrepreneurship spirit powerfully. The results of this analysis indicated at the table 5.

Table 5: the results of multiple regressions analysis to examination of predicting relationship between organizational climate dimensions in educating entrepreneurship spirit

\begin{tabular}{|c|c|c|c|c|}
\hline Model & $\mathrm{t}$ & Beta & B & Sig \\
\hline (Constant) & $10 / 585$ & & $13 / 415$ & $0 / 000$ \\
\hline Community spirit & $1 / 567$ & 0/107 & $0 / 082$ & $0 / 003$ \\
\hline Disturbance & $-0 / 704$ & $-0 / 051$ & $-0 / 032$ & $0 / 482$ \\
\hline Devotion & $1 / 182$ & $0 / 090$ & $0 / 059$ & $0 / 239$ \\
\hline Interest & $-0 / 362$ & $-0 / 026$ & $-0 / 018$ & $0 / 717$ \\
\hline Regarding & $0 / 120$ & $0 / 009$ & $0 / 005$ & $0 / 905$ \\
\hline Avoidance & $0 / 746$ & $0 / 053$ & $0 / 034$ & $0 / 456$ \\
\hline Influence and dynamics & 3/091 & $0 / 244$ & $0 / 150$ & $0 / 002$ \\
\hline Focus on production & $0 / 179$ & $0 / 013$ & $0 / 008$ & $0 / 858$ \\
\hline
\end{tabular}

The results of multiple regressions analysis indicated that there is significant relationship between influence and dynamics, community spirit in educating entrepreneurship spirit, whereas disturbance, devotion, interest, regarding, avoidance, and focus on production haven't significant role in predicting entrepreneurship spirit.

\section{Discussion and conclusion}

University, as small society and because of dominance of complex network of human interactions, provides the defined social climate that influences the multi-dimensional growth and education of student's personality. Also with respect to rapid increase of new competitors and also sense of unreliability toward traditional methods of management in all systems especially educational system, the revolution in systems especially educational systems and move toward educating creative and entrepreneurship individuals in such organizations is necessary. In order to this, the role of dynamic organizations is to discovering and educating creative and entrepreneurship individuals. Which organization that can't actualize its internal competencies, then restrain by other organizations. 
Universities can provide the appropriate environments to educating entrepreneurship spirit through identifying environmental, economic, cultural, and technological factors and applying them. University, as small society and because of dominance of complex network of human interactions, provides the defined social climate that influences the multi-dimensional growth and education of student's personality. In this study the first question that we answer to it is that what is amount of measures of entrepreneurship spirit between graduate students of university of Isfahan? Then the results indicated that amount of risk, creativity, control, achievement, and autonomy were more than average level (3) (with $\mathrm{p}<0 / 05$ ), also the most value was for autonomy dimension with mean 3/72 and the lowest value was for creativity with mean 0/02. This result supported by Badri (2005), Samadi (2007), and Anderson (1982) and indicated that amount of entrepreneurship spirit were more than average. Also with respect to results of study, there isn't significant relationship between these factors in terms of gender differences. The results of second questions indicated that there is significant relationship between organizational climate with educating entrepreneurship spirit, also this result supported by Anderson (1982), Rabinson and others (1991), Heydari and others (2010), Esmi and Jahani (2009), and Kedyour (1999). The results of this study also indicated that there isn't significant relationship between organizational climate with two dimensions of educating entrepreneurship spirit (risk-taking and autonomy). There are many reasons for this such as manner of growth, individual family life, passiveness of personality, lack of participation plans and decisions, closed climate of learning and impractical side of book's contents, lack of necessary and effective educations, and also lack of student's participation in daily issues. There isn't any relationship between three other dimensions including achievement, creativity, and inner control with organizational climate. This result supported by Holpin and Craft (1962), Shirzadi (1986), Rabinson and others (1991), Ahmad (1985), Ehsan (2006), Pourkiani and Abdali (2009), Jahroumi and others (2009). Also Youterberg (1979), Pearson and Delback (1997) indicated in their studies that there is relationship between organizational structure with amount of creativity and innovation of individuals and also flexible structure leads to progress and development in learning ideas and new viewpoints. Also amount of these structure's creativity and innovation are more than inflexible structures.

With respect to these findings and in order to providing more efficient academic systems, it is suggested that managers and professionals attend to following suggestions and applying them:

1. based on the positive relationship between devotion and entrepreneurship spirit, it is suggested that managers provide multiple relationships between professors, students, and administrative managers and also identifying individual differences and also inter-respect together that lead to multi-dimensional actualization and growth of all sides.

2. Reinforcing and improving student's responsibility, self-esteem, and autonomy through participating them in administrative affairs of faculties and university.

3. Providing challenging goals for students in academic environments that leads to increasing 
their responsibility, individual efforts and strives in order to achieving goals and objectives. This leads to increasing their motivation to progress and it is expected that their inner control and rik-taking increase.

4. Communicating universities with research and industrial centers more and more.

5. Making courses practical and applicable with conceptual theories so that complete them together.

6. Communicating detritions dimension with entrepreneurship spirit that leads to attending this issue that prevention and blackness in student's path leads to discouraging them.

7. Providing open environment based on inter-perception and agreeableness between students leads to making plans more efficiency, preventing abuse, maximizing time consumption, human, and financial resources.

8. With respect to our findings, if the academic systems move toward supportive behavior, interest, facilitating, and flexibility, then this leads to increasing member's satisfaction, creativity, self-esteem.

\section{References}

Shirzadi, Homa, (2006), Examining School's organizational Climate with Entrepreneurship Sprits between Students, MA Thesis, University of Tehran.

Samadi, Parvin, Isfahani, Homa, (2007), Examining Relationship between School's Orgnizational Climate between Students, Journal of Educational Innovations, Vol 16.

Farahani, Abolfazl, (2009), the Role of Headline and contents of Sport Sciences Courses in Entrepreneurship of this Field's Graduates, Journal of Sport Management, Vol 1, pp 203-223.

Fakor, Bahman, (2008), The Entrepreneurship University: the Concepts, backgrounds, and Accessing manners, Journal of Parks and Growth Centers, University of Tehran.

Kedyour, Parvin, (2008), Examining Organizational Climate in Tehran's Schools, Journal of Human Sciences, Alzahra university, Vol 300, p 121.

Nahid, Mojtaba, (2009), Why and How Entrepreneurship, Journal of Commercial studies, Vol 34, pp 39-58.

Aderson Carolyn, S (1982). The Search For School climate: A Review of the research. Review of educational research, Vol.52,pp368-420.

Antoncic, Boston. Hisrich, Robert. (2003). Clarifying the enter Premiership Concept. Journal of small business and enterprise Development, 7-24.

Asadi, Ali, Ghasemi, Javad, (2010), The Factor Analysis of Influencing Variables on Creating Entrepreneurship Sprits among Graduate Students, Journal of Economic and Articular Development, 24(1): pp13-22.

Halpin, A. Croft, D. (1963). The organizational Climate of school Chicago: Midwest Administration center of the University of Chicago.

Esmi, Keramat, Jahani, Jafar, (2009), Examining Relationship between Organizational Structure and Organizational Creativity at High schools of Shiraz, Journal of Leadership and Educational Administration, Garmsar branch, Islamic Azad University, 3(1), pp 9-28.

Emaminejhad, Masoud, (2004), Entrepreneurship in organizational Structure as Suitable 
Factor to Organizational, Management, Quality, and Entrepreneurship Development, Monthly of Management, Vol 14, pp 89-90.

Badri, Ehsan, (2005), Examining Entrepreneurship Competencies of University of Isfahan's Students, MA Thesis, Faculty of educational sciences and psychology, Isfahan, Iran.

Pourkiani, Mohamad, Abdolali, Behroz, Examining Relationship between Organizational Climate of Sport Faculties and Departments and Entrepreneurship Sprits between Male Students, Journal of Research in sport sciences, Vol 23, pp 123-136.

Jaribi, Jafar, (2004), Developing Entrepreneurship and Graduates, Journal Research and and Planning in High Educations, Vol 300, p 160.

Jahromi, Shapour, (2009), Examining relationship between Organizational Climate, Organizational Commitment, and Sprit from Teacher's perspective, Journal of Modern Manner in Educational Administration, 2(3), pp 109-130.

Khedmati, Tavasoul, Examining Backgrounds of educating Entrepreneurship in male High schools from Teacher's Perspective, MA Thesis, Shahid Beheshti University.

Zabihi, Abas, (2004), Quality Management and Entrepreneurship, Monthly of Management, Vol 14.

Zahedi, Shamsossadat, (2003), the Systemic Analysis of Influencing Alternatives on Entrepreneurship Phenomenon, Conference of Entrepreneurship and Developed Technology, Tehran: Publishers of University of Isfahan.

Heydari, Zahra, (2010), examining relationship between Organizational Climate and Conflict Management from Teachers perspective, Journal of Modernity in Industrial and Organizational Psychology, 1(3), pp 65-74.

Kutlnlaht. (2006). Universities approaching market intertwining goals, Osco. (1996). The knowledge. Based economy. Paris .

Pal, S. \& Saxean, P. (1985). Quality control in education research: Metrolition, New Delhi .

Pierce J, Delbecq A. (1979). Organization structure, individual attitudes and innovation: academy of management review, pp 22-37 .

Rashed, H. (2000). Developing entre preneurial potential in youth the effect of entrepreneurial education and yenture creation. Avaliable: wwwproquest. Com

Timmons, J. (1990). View venture creation Boston IRWIN .

Zampetakis, A. Leonidas, A. Beldekos, A, Panagiotis. Moustakis Avassilis

S. (2009). "day-to-day" entrepreneurship within organizations: the role of trait emotional intelligence and perceived organizational support. European management Journal, 27, 165-175 . 